\title{
Biological Diversity of the Green Mussel Perna viridis (L.), Mytilidae, Community from Bahadurgad Island off Malpe South West Coast of India.
}

\author{
HEMACHANDRA ${ }^{{ }^{*}}$ and SEETHARAMAYYA THIPPESWAMY ${ }^{2}$ \\ ${ }^{1}$ Department of Zoology, St. Aloysius College, \\ Mangalore, Karnataka, India. PIN-575006 \\ ${ }^{2}$ Department of Environmental Science, Mangalore University, \\ Mangalagangothri, Mangalore, Karnataka, India. PIN-574199.
}

\begin{abstract}
The biological diversity of the green mussel Perna viridis (L.), Mytilidae, community was studied at Bahadurgad Island off Malpe, near Udupi, south-west coast of India. A total of 4,262 individuals belonging to 94 species were recorded. The green mussel Perna viridis was rich in both number and biomass. The intertidal biodiversity of Bahadurgad Island was composed of algae (11 spp.), porifera (1 sp.), coelenterata (4 spp.), platyhelminthes (2 spp.), aschelminthes (1 sp.), ectoprocta (4 spp.), annelida (24 spp.), mollusca (22 spp.), arthropoda (23 spp.), echinodermata (1 sp.) and fish (1 sp.). Among polychaetes, the genera Phyllodoce with four species, Eulalia and Perineries with three species each and Neries with two species were encountered. Rest of the genera was represented by a single species each. Among crustaceans, the maximum species richness was contributed by decapoda comprising ten species of crabs, one species of shrimp (Alpheus malabaricus) and amphipoda (6 spp.), cirripedia (5 spp.) and isopoda (1 sp.). The genera Modiolus (M. modiolus, Modiolus sp.) and Thias (T. rustica, T. tissoti) were represented by two species each. Chitons were represented by Acanthopluera granulata and Ischiochiton ruber. Hydroid was represented by three species (Clava leptosyla, Lovenella gracilis, Tubularia sp.). Sea anemones with two species (Haliplanella sp., Clava leptosyla) were recorded. During the study period, Chthamalus sp. (1,566 ind.) was dominant, followed by Perna viridis (944 ind) and Trochus radiatus (42 ind.). The species diversity (log, H') ranged from 1.4009 to 2.5296 . The minimum (0.4119) and maximum (0.6466) values of evenness were recorded during monsoon (September 2006) and post-monsoon (December 2005) seasons, respectively. The species diversity was affected more by the distribution of individuals among species. Analysis of hierarchical cluster with complete linkage revealed the presence of two large groups. Group A was composed of coelenterates, gastropods, cirripedes, decapods, bivalves, amphipods, bryozoans, whereas group B consisted of algae, polyplacophora, polychaeta and others (porifera, platyhelminthes, aschelminthes, isopoda, echinodermata, fish). The Principle Component Analysis yield three components with Eigen value more than one. The component
\end{abstract}

\footnotetext{
* Corresponding Author.

Email : muhevirgo@yahoo.com
} 
one (bryozoa, amphipoda, air temperature, water temperature, mussel bed temperature, $\mathrm{pH}$, salinity and dissolved oxygen) accounted for $40.78 \%$ of variation, followed by component two (coelenterata, gastropoda, cirripedia, decapoda, porifera, aschelminthes, echindodermata, chordata) that accounted for $39.66 \%$ of variance and component three (algae, polychaetes, polyplacophora, bivalves, rainfall) accounted for $19.56 \%$ of variance.

\section{Introduction}

Island ecosystems are delicately balanced and have long been noted for their unique biological diversity. The isolation and small size of islands can be seen as both advantageous and disadvantageous. Because islands are isolated from the mainland, new species might be developed. But because of their small size, any imbalance can have a great impact. In recent days, the biodiversity of islands is subjected to disturbances and destruction. The introduction or removal of a species causes problems across the whole ecosystem. With the increasing rate of global change, islands represent some of the most fragile and vulnerable resources on the planet. Data on biological diversity is important to understand the magnitude of production (Leigh et al. 1987), energy pathways (Porter et al. 1996; Grall and Chavaud 2002; Raffaelli et al. 2003), ecosystem conservation (Widdows and Donkin 1992) and also to evaluate the environmental and anthropogenic effects (Lubchenco et al. 1984; Menge et al. 1986, Loot et al. 2005) on the biota. The composition, structure and diversity of marine mussel community have been documented (Suchanek 1979, 1980; Briggs 1982; Tsuchiya and Nishihira 1985; Commito 1987; Seed and Suchanek 1992; Lintas and Seed 1994). It is well known that large number of small animals inhabit in mussel patches, crevices of rocks, rock pools and on sessile organisms such as mussels (Hasomi 1967; Keith 1971; Paine 1971, 1976; Seed 1976; Dean 1981; Paine \& Levin 1981; Roughgarden et al. 1988; Lohse 1993; Menge 1991, 1992; Menge et al. 1994; Petraitis et al. 2003). Scattered information is available on the composition of the intertidal regions of the Indian coast including some islands. There is a dearth of information on intertidal diversity of Bahadurgad Island off Malpe, near Udupi. Therefore, the present study was undertaken to study the intertidal biological diversity at Bahadurgad Island, one of the islands of St. Mary's group of islands off Malpe, near Udupi, south west coast of India.

\section{Materials and methods}

The study area consists of a small group of four islands collectively known as St. Mary's islands spread over a distance of $4 \mathrm{~km}$ from north to south off Malpe near 
Udupi and has a rocky outcrop attaining a height of approximately $25 \mathrm{~m}$ (Naganna 1966). There is no human inhabitant in this island and tourists do not visit the island. Fishermen collect the large sized mussels from this island. Samples were collected

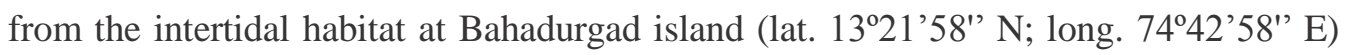
during December 2005 (post-monsoon), March (summer), May (pre-monsoon) and September 2006 (monsoon). At the time of each sampling, air, water and mussel bed temperatures were recorded. The $\mathrm{pH}$, salinity and dissolved oxygen of sea water were estimated (Strickland \& Parsons 1968). The data on rainfall (mm) during the study period were obtained from the Office of the District Statistical Officer, Government of Karnataka, Udupi. At the study site, first algae were removed and the entire contents (mussels, sediment, fauna) were then removed from one square feet and brought to the laboratory. In the laboratory, mussels and associated fauna were separated. The density (ind. $\mathrm{m}^{-2}$ ) of mussels was estimated. Subsequently, the fauna were segregated into major groups and preserved in 5\% formaldehyde or $70 \%$ alcohol, identified and counted. Each colony / holdfast of algae, hydroids, bryozoans and molluscan egg mass was considered as one unit for calculation purposes. Shannon-Weaner density index (Shannon \& Weiner 1949) and evenness (Pielou 1975) were calculated. The data were analysed by two methods, Principle Component Analysis (PCA) to find the number of components that can adequately explain the observed correlations among the observed variables and Cluster Analysis (CA) to elucidate the association of organisms (Davis 1973; Lewis-Bek 1994).

\section{Results}

A total of 94 species of sea weeds and marine fauna were recorded during the study period from the intertidal habitat of Bahadurgad Island and the data are presented in Table 1. A total of 11 species of seaweeds belonging to ten genera were recorded during the study period. Of these, the genus Gracilaria was represented by two species (Gracilaria corticata, G. crassa, Gracilariaceae). The maximum number of species (6 spp.) was recorded during the post-monsoon season followed by monsoon (4 spp.) and summer (3 spp.). Seaweeds were not recorded during the summer in the mussel community. A total of 83 species belonging to ten phyla comprising 4248 individuals of fauna were recorded during the course of the study period (Table 1). Aschelminthes were recorded only during pre-monsoon with two individuals. The maximum species richness was contributed by polychaeta (24 spp.) followed by arthropoda (23 spp.) and mollusca (22 spp.). 
Table 1. Biological diversity recorded from Bahadurgad Island during the study period. Number represents the density (no. $\mathrm{ft}^{-2}$ ).

\begin{tabular}{ccccc}
\hline Species & $\begin{array}{c}\text { Post-monsoon } \\
\text { (December '05) }\end{array}$ & $\begin{array}{c}\text { Summer } \\
(\text { March '06) }\end{array}$ & $\begin{array}{c}\text { Pre-monsoon } \\
\text { (May '06) }\end{array}$ & $\begin{array}{c}\text { Monsoon } \\
\text { (September '06) }\end{array}$ \\
\hline
\end{tabular}

Algae

Acanthophora spicifera

Centrocerks clavulatum

1

Chaetomorpha antennina

Codium dicorticatum

Enteromorpha compressa

Gigartina acicularis

Gracilaria corticata

G. crassa 1

Padina gymnospora 1

Sargassum wightii $\quad 1$

Ulva fasciata

Phylum: Porifera

Haliclona palmata

Phylum: Coelenterata

Clava leptostyla

Haliplanella sp.

Lovenella gracilis

Tubularia sp.

Phylum: Platyhelminthes

Gnesioceros sp.

Prosthiostomum sp.

Phylum: Aschelminthes

Unidentified nematode

Phylum: Ectoprocta

Alcyonidium sp.

8

Caberea sp.

Lichenopora hispida

Tricellaria peachii

Phylum: Annelida

Eulalia (Eunida) sanguine 4

E. albo-picta 
E. viridis

Hydroides exaltatus

Lopadorhynchus uncinatus

Lumbrioneries notocerrata

Mercierella enigmatica

Nephthys inermis

3

Neries (Ceratoneries) costae

Neries sp.

Perineries cultrifera

P. nunita

Phyllodoce castanea

P. fristidii

P. quadraticeps

Phyllodoce sp.

Platyneries coccinia

Polymnia nebulosa

Pomatoceros sp.

Psuedoneries gallapogenesis

Sabella melanostigma

Serpula vermicularis

Syllis gracilis

Phlum: Mollusca

Acanthopluera granulate

Acmaea sp.

Babylonia spirata

Branchiodontes modiolus

Bursa tuberculata

1

Cantharus undosus

1

Cardium setosum

Cellana radiate

Clypidina notate

2

Cymatium aquatile

1

Euchelus tricarinata

Ischiochiton ruber

Littorina undulate 
Modiolus modiolus

Modiolus sp.

Morula nodulosa

Perna viridis

Thias rustica

T. tissoti

Trochus radiates Turbo

eggmass Phylum :

Arthropoda Alpheus

malabaricus

Amphithoe inda

Balanus amphitrite

B. a. communis

$B$. reticulates $B$.

variegates

Chthamalus sp.

Charybdis callianassanus

Estius laevimanus

Eurycarcinus orientalis

Grapsus strigosus

2

Hyale hawaiensis

$$
181
$$

Hyale sp. 1

Hyale sp. 2

Leptodius crassimanus 262

Leucothoe sp.

Moera sp.

Ozius rugulosus

Platypodia cristata

sesarma occenica

Xantho scabbarimus

Phylum: Echinodermata

Ophiophragmus sp.

\section{Phylum : Chordata}

Aspidontus striatus 
The phyla coelenterata and bryozoa were represented by four species each followed by the polychaete worm with two species. Sponge (Haliclona palmata, Chalinidae, brittle star (Ophiophragmus sp.) and fish (Aspidontus striatus, Blenniidae) were represented by a single species each. Aschelminthes was represented by two species (Prosthiostomum sp., Gnesioceros sp.). The species richness and abundance of biological diversity is presented in Fig 1. The maximum number of species was contributed by polychaeta $(22.63 \%)$ followed by gastropoda (16.79\%), decapoda (13.14\%), algae $(9.49 \%)$, cirripedia $(7.3 \%)$, others $(7.3 \%)$, bivalvia (6.57\%) and amphipoda (6.57\%). The remaining components were coelenterata $(4.37 \%)$, bryozoa (2.92\%) and polyplacophora (2.92\%). The group others included porifera, platyhelminthes, aschelminthes, isopoda, echinodermata and fish. An examination of the numerical dominance in the major components
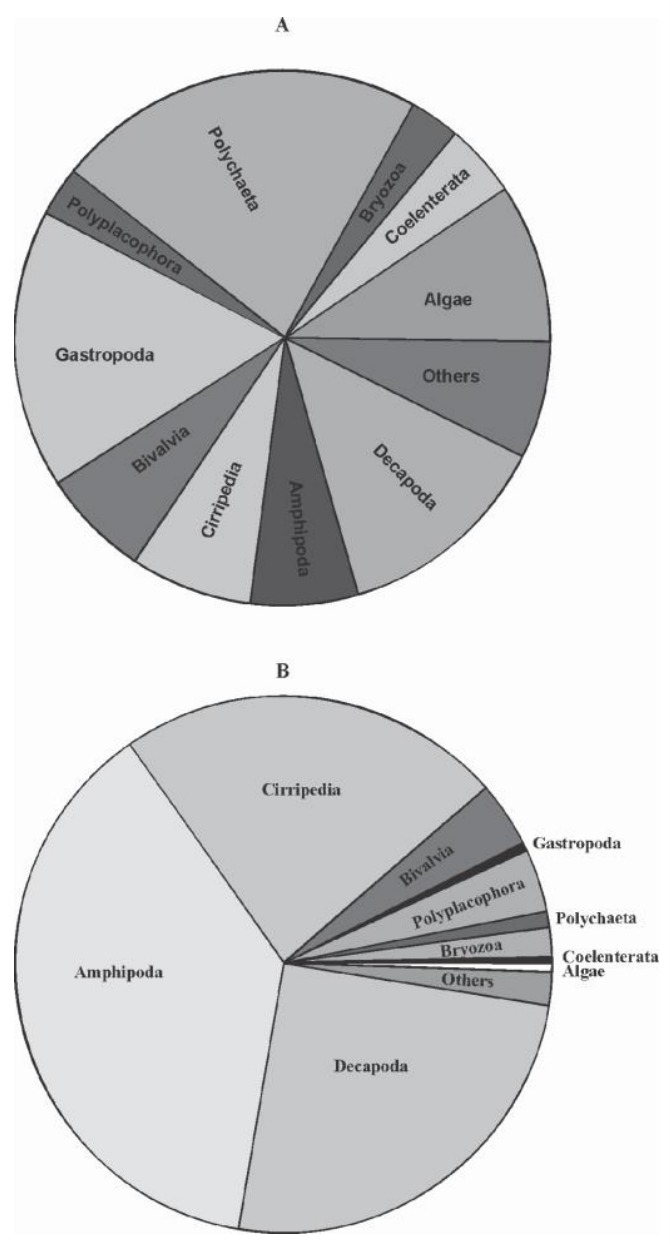

Figure 1. Species richness (A) and numerical abundance (B) of mussel community at Bahadurgad island. The group others included sponge, flat worms, round worms, echinoderms and fish in the mussel community showed that more than 95\% were contributed together by arthropoda $(64.73 \%)$ (i.e. cirripedia (37.66\%), amphipoda (24.98\%) and decapoda (2.09\%)), mollusca (27.8\%) (i.e. polyplacophora $(0.35 \%)$, gastropoda $(4.2 \%)$ and Bivalvia $(23.25 \%)$ ), and polychaeta (3.99\%). Less than $5 \%$ was contributed together by coelenterata $(1.81 \%)$, algae $(0.33 \%)$ and others $(0.54 \%)$.

A total of 24 species belonging to 16 genera comprising 170 individuals of polychaetes were recorded during the study period. Among these, the genera Phyllodoce comprising of 4 species, Eulalia and Perineries with three species each, followed by 
Neries with two species, were encountered. Rest of the genera was represented by a single species each. The maximum species richness was noticed during summer (19 spp.) and pre-monsoon (6 Spp.). However, during summer, only two species (Perineries nunita, Phyllodoce castanea) were encountered. The maximum density of polychaetes was noticed during post-monsoon season (102 ind.) followed by (50 ind.), monsoon (15 ind.) and summer ( 3 ind.). A total of 2763 individuals of crustaceans belonging to 23 species of 16 genera were recorded during the study period. Among these, the maximum species richness was contributed by decapoda comprising ten species of crabs and one species of shrimp (Alpheus malabaricus), followed by amphipoda (6 spp.), cirripedia (5 spp.) and one species of isopoda. The minimum and maximum densities of crustacea were 130 (post-monsoon) and 150 ind. $\mathrm{ft}^{-2}$ (pre-monsoon), respectively. The genus Balanus was represented by four species, followed by Hyale (3 spp.) and Sesarma (2 spp.). Rest of the genera was represented by a single species each. The maximum species richness was registered (14 spp.) during pre-monsoon, whereas in other seasons, the richness was more or less the same (7-9 spp.)

A total of 21 species belonging to 19 genera comprising 1186 individuals of mollusca were recorded. Molluscan egg mass was recorded during summer. The genera Modiolus (M. modiolus, Modiolus sp.) and Thias (T. rustica, T. tissoti) were represented by two species each. Rest of the genera was represented by a single species each. Chitons were represented by Acanthopluera granulata and Ischiochiton ruber. A total of 14 species of gastropods, followed by five species of bivalves were encountered during the study period. The maximum density of gastropods was noticed during pre-monsoon (401 ind. $\mathrm{ft}^{-2}$ ), followed by monsoon (316 ind. $\mathrm{ft}^{-2}$ ), summer (276 ind. $\mathrm{ft}^{-2}$ ) and postmonsoon (193 ind. $\mathrm{ft}^{-2}$ ). Perna viridis, Mytilidae, Cellana radiata, Nacellidae and Trochus radiatus, Trochidae, were recorded during all the seasons. Babylonia spirata, Bursa tuberculata, Cantharus undosus, Buccinidae, Cardium setosum, Cardiidae, Clypidina notata, Fissurellidae Emarginulinae, Cymatium aquatile, Trichoniscoidea, Ischiochiton rubber, Littorina undulata, Modiolus modiolus, Morula nodulosa and Turbo brunneus were recorded only once during the study period. The maximum species richness was noticed during the post-monsoon season (11 spp.) followed by summer and monsoon with nine species each. Only seven species of mollusca were recorded during pre-monsoon. A total of four species comprising 77 individuals of coelenterata were recorded during the post-monsoon and monsoon seasons. Among coelenterates, hydroid was represented by three species (Clava leptosyla, Lovenella gracilis, Tubularia sp.). Sea anemones with two species (Haliplanella sp., Clava leptosyla) were recorded during pre-monsoon (49 ind.). During summer, coelenterates, platyhelminthes, aschelminthes and ectoprocta were not encountered in the mussel bed. Among bryozoans, 
Caberea sp., Lichenopora hispida and Tricellaria peachii were recorded only during monsoon, whereas Alcyonidium sp. was recorded during premonsoon season only. During post-monsoon and summer seasons, bryozoans were not encountered in the community.

Seasonal variation in the species diversity (ShannonWeaner index, H'), the distribution of individuals among species (evenness) and number of species (H' max) are presented in Fig 2. During the study period, the maximum species diversity was observed during the post-monsoon $\left(\mathrm{H}^{\prime}=\right.$ 2.5296) when 449 individuals belonging to 50 species were recorded, followed by premonsoon $\left(\mathrm{H}^{\prime}=2.0682\right)$ when 2016 individuals were distributed among 35 species. In summer and monsoon, the $\mathrm{H}^{\prime}$ were 1.6017 and 1.4009 natural bel, respectively. During summer and monsoon seasons, a total of 794 individuals belonging to 22 species and 1003 individuals belonging to 30 species were recorded. The minimum (0.4119) and maximum (0.6466) evenness $(\mathrm{J} ')$ were noticed during monsoon and post monsoon

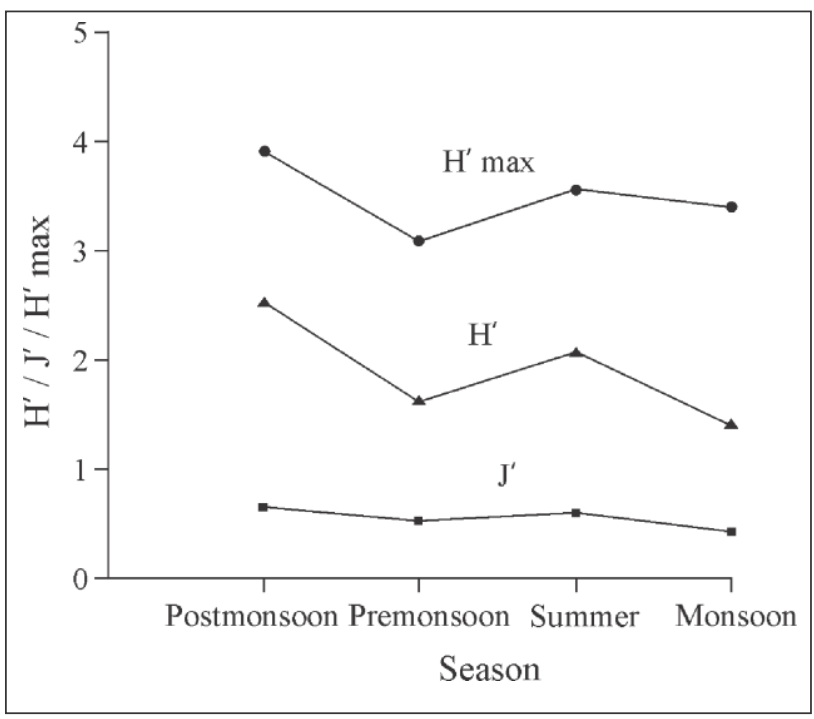

Figure 2. Seasonal variation in species diversity $\left(\mathrm{H}^{\prime}\right)$, evenness (J') and $\mathrm{H}^{\prime} \max$.

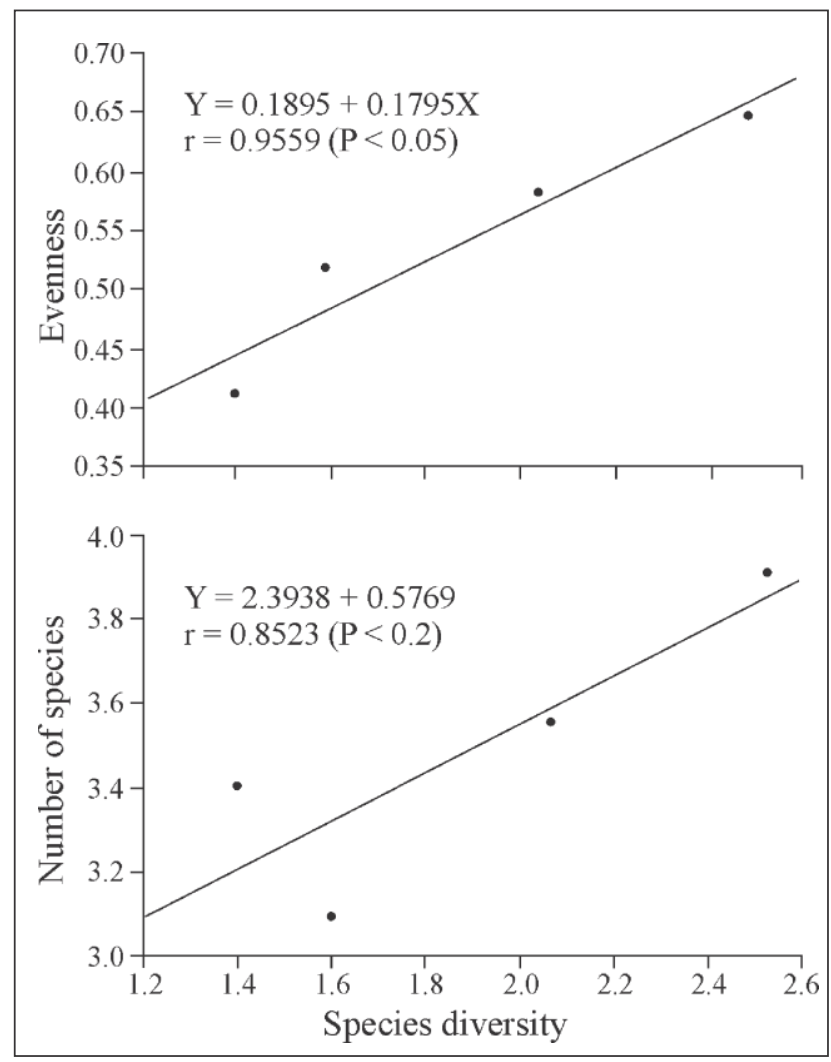

Figure 3. Relation between species diversity, evenness and species diversity and number of species. 
seasons, respectively. During summer and pre-monsoon seasons, the evenness values were 0.5182 and 0.5817 , respectively. The number of species (H' max) was minimum in summer (3.091) and maximum in post-monsoon season (3.912). Relationship between species diversity and evenness and species diversity and $\log$ number of species (H' max) is depicted in Fig 3. The linear relationship between species diversity and evenness and species diversity and number of species were $\mathrm{Y}=0.1895+$ $0.1795 \mathrm{X} \quad(\mathrm{r}=0.9559$, $\mathrm{P}<0.005)$ and $\mathrm{Y}=2.3938+$ $0.5769 X(r=0.8523, P<0.2)$, respectively. Analysis of hierarchical cluster with complete linkage revealed the presence of two large groups (Fig 4).

Group A, with three subgroups A1 (coelenterata, gastro poda, cirripedia, deca poda, bivalvia, amphi poda) and A2 (bryozoa) and Group B with two subgroups B1 (algae, polyplacophora, poly chaeta) and B2 (others including porifera, platyhelminthes, aschelminthes, isopoda, echinodermata and fish). The PCA yield more detailed picture of the interaction of biological diversity

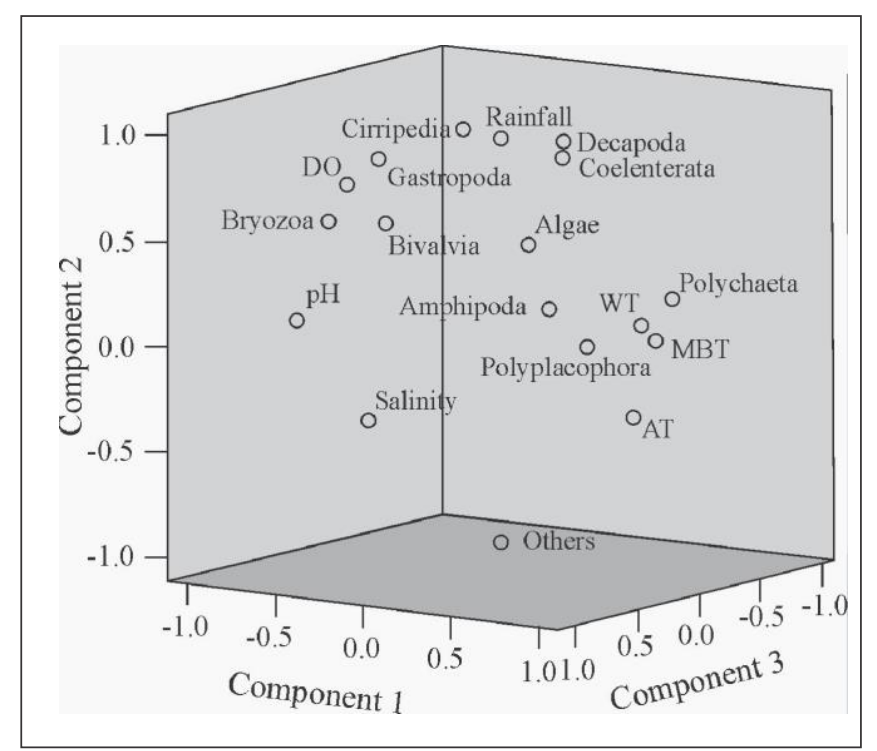

Figure 4. Dendrogram using complete linkage for major groups of mussel community.

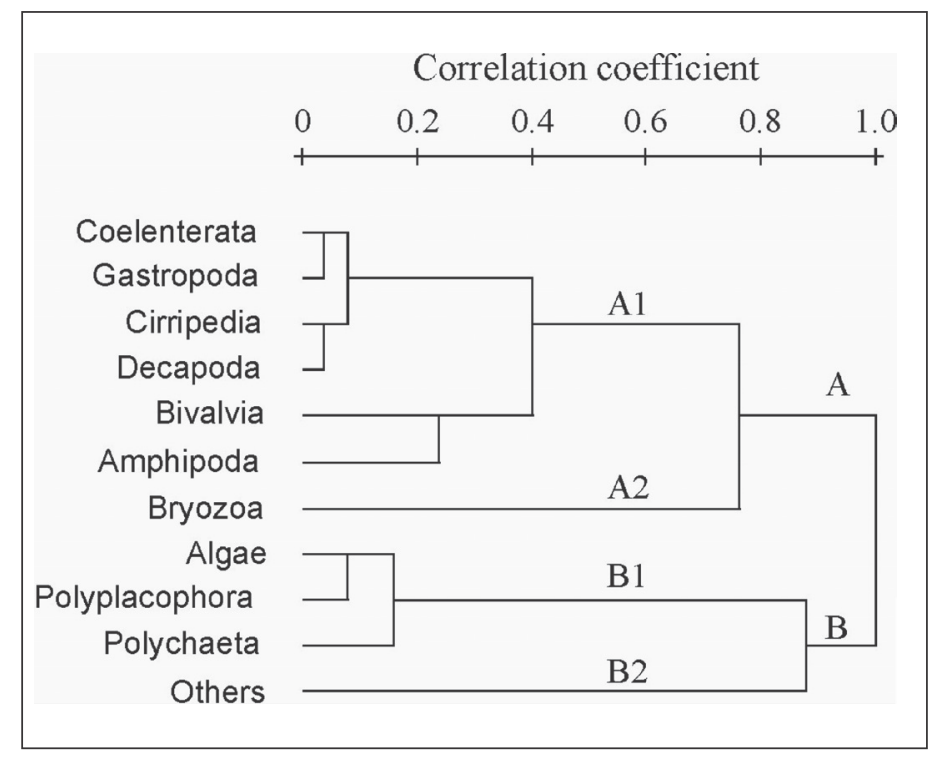

Figure 5. Component plot in rotated space. and environmental parameters (Fig 5). 
A total of three components showed Eigen value more than one in the present study. The component one (bryozoa, amphipoda, air temperature, water temperature, mussel bed temperature, $\mathrm{pH}$, salinity, dissolved oxygen, rainfall) accounted for $40.78 \%$ of variation, followed by component two (coelenterata, gastropoda, cirripedia, decapoda, porifera, aschelminthes, isopoda, echindodermata, chordata) which accounted for $39.66 \%$ of variance and component three (algae, polychaetes, polyplacophora, bivalves) accounted for $19.56 \%$ of variance.

\section{Discussion}

A good deal of information on associated flora and fauna of mussels from temperate region is available. Kanter (1977) and Suchanek (1979) reported a total of 200 species of invertebrates in Mytilus californianus bed. Briggs (1982) reported a total of 34 species of associated organisms with M. edulis in Ireland waters. Tsuchiya and Nishihira (1985) reported 69 species of invertebrates in mussel patch at Asamushi, Japan. Lintas and Seed (1994) have recorded a total of 59 taxa in the beds consisting of M. edulis and M. californianus. Thippeswamy (1990) reported 258 species of associated organisms of green mussel, Perna viridis microhabitat at Someshwar, near Mangalore, India. During the present study, a total of 94 species comprising sea weeds, invertebrates, and fish were collected at the study site. Of these, 11 species of algae belonging to ten genera and 87 species of fauna comprising 3277 individuals were recorded. Among 11 species of seaweeds recorded, nine species were encountered only once, whereas two species (Chaetomorpha antennina, Gigartina acicularis) were recorded twice. A total of six species (Chaetomorpha antennina, Codium dicorticatum, Gigartina acicularis, Gracilaria crassa, Padina gymnospora and Sargassum wightii), three species (Acanthophora spicifera, Centrocerks clavulatum, Gracilaria corticata) and four species (Chaetomorpha antennina, Enteromorpha compressa, Gigartina acicularis, Ulva fasciata) of algae were recorded during post-monsoon, pre-monsoon, and monsoon seasons, respectively. Seaweed was not represented during summer. A large number of algal species in post-monsoon and low number in winter have been reported in Paradise point at Karachi (Fatima 1996).

One species of sponge Haliclona palmata was recorded in all the seasons, except monsoon, in the present study. Coelenterates were found in all seasons, except during summer. One species of nematode was observed only in summer season. During summer and monsoon seasons 2 spp. and 1 sp. of ectoprocta, respectively, were recorded. Polychaetes were found in all seasons. They were numerically abundant in post-monsoon followed by pre-monsoon. Only two species of polychaetes were recorded in summer. Molluscs were recorded during the entire study period. The numerical dominance was 
noticed in pre-monsoon followed by monsoon. Arthropods were associated with mussel community during the entire study period. Among arthropods, barnacles were numerically abundant and their peak of abundance coincided with the stable and protective adult mussel bed. Large number of barnacles, (Chthamalus sp.) settle on the large mussel shells, thus utilizing the mussel microhabitat and hence, high abundance. The numerical abundance was noticed in pre-monsoon and monsoon seasons.

Number of species and even distribution of individuals per species are the two important components of species diversity, which increases with increased number of species and more even distribution of individuals per species. Therefore, diversity measures both species richness and species evenness (distribution of individuals among species) in the community (Pielou 1975). During the study period, the values (using natural $\log$ ) of Shannon-Weaner index varied from 1.4009 (monsoon) to 2.5296 (postmonsoon). Tsuchiya \& Nishihira (1985) reported the values of species diversity (using $\log _{2}$ ) of $3.154,4.274,4.245$ and 3.537 for young, peripheral, central and old mussel patches at Asamushi, Japan.

During monsoon a total of 1003 individuals were distributed among 30 species. However, during this season density of P. viridis and Chthamalus sp. were 263 and 582, respectively. Rest of the individuals (158) were distributed among 28 species. Diversity was low (1.4009) during monsoon season when large number of $P$. viridis and Chthamalus sp. settled. Therefore, the low diversity index was due to low evenness (0.4119). During post-monsoon, 449 individuals were distributed among 50 species, the H' being 2.5296 . During this season the highest density of $P$. viridis (155 ind.) and Chthamalus sp. (112 ind.) was noticed. The rest of 182 individuals were distributed among 48 species. The estimated J' was 0.6466 that indicated a more even distribution of individuals among species during this season. This concept is further supported by the linear regression relationship $(\mathrm{Y}=0.1895+0.1795 \mathrm{X}, \mathrm{r}=0.9559, \mathrm{P}<0.05)$ between $\mathrm{H}^{\prime}$ and $\mathrm{J}^{\prime}$ (Fig 3). Thus, the diversity is affected by the distribution of individuals among species. During the study period, the species richness varied from 22 (summer) to 50 (post-monsoon) species. Species diversity of mussel community during summer and post-monsoon were 1.6017 and 2.5296, respectively. During pre-monsoon and monsoon seasons the values of Shannon-Weaner index were 2.0682 and 1.4009 natural bel, respectively. The diversity values were indirectly proportional to the species richness in summer $(22 \mathrm{spp}$.) and monsoon (30 spp.). Therefore, the diversity is poorly correlated with species richness. The regression equation between $\mathrm{H}^{\prime}$ and $\mathrm{H}^{\prime}$ max was $\mathrm{Y}=2.3938+0.5769 \mathrm{X}(\mathrm{r}=0.0 .8523$, $\mathrm{P}<0.2$ ). Therefore, it can be concluded that the diversity is affected more by the even distribution of individuals among species than species richness and number of species. 
The hierarchical CA showed the close interaction between the groups (Fig 4). Coelenterata, gastropoda, cirripedia, and decapoda form one subgroup. Coelenterates and cirripedes grow on gastropod shells and also on decapods. Coelenterates grow on bivalves. Gastropods and decapods (crabs) have prey-predator relationship with bivalves. Gastropods are also significant predators on mussels and choose their prey on the basis of profitability (i.e. the potential energy gain from a food item relative to handling time), which increases with prey size (Seed 1996). He further reported that gastropods could consume up to two mussels (1-3 cm in shell length) per week in summer, at the height of their predatory activity. Predation by crabs on plantigrades of mussels has been demonstrated by Harger (1972) and Rovero et al. (2000). Bryozoa formed a separate subgroup and it is dependent on mussels for space and food. Algae, polyplacophora, polychaeta and others (sponge, round worm, isopod, sea star and fish) formed a separate group. Chitons coexist with algae and polychaetes. Many polychaetes consume fresh algae (Joseph 1978), isopods and some polychaetes are omnivores (Levington 1982). Mussels are dominant competitors, they are able to exploit their resources, quickly outcompete other competitors, dominate the available space and ultimately reduce the species diversity on the rocky substrate. The interaction of environmental factors on the community composition was analyzed using PCA (Fig 5). The component one included nine Eigen vectors (bryozoa, amphipoda, air temperature, water temperature, mussel bed temperature, $\mathrm{pH}$, salinity, dissolved oxygen, rainfall). The components two and three included only Eigen vectors of biological variables. The component two included five Eigen vectors such as coelenterata, gastropoda, cirripedia, decapoda and others (porifera, aschelminthes, isopoda, echindodermata, chordata) whereas the component three included four Eigen vectors (algae, polychaetes, polyplacophora, bivalves) of biological variables. The vectors such as amphipods, air, water and mussel bed temperatures of component one, others of component two algae, polychaetes and polyplacophora of component three show negative values. The effect of the environmental factors (except rainfall) was noticed more on algae, bryozoans and amphipods. Rainfall affected the population of coelenterates, polychaetes, chitons, gastropods, bivalves, cirripedes, decapods and others. Intertidal systems are dynamic environments, constantly subjecting their inhabitants to varying conditions of temperature, humidity and salinity, as well as physical disturbance from storms and wave action (Creese \& Kingsford 1998; Madarasz, unpubl. data). While varying levels of temperature, salinity and nutrients reaching intertidal communities could result from hydrodynamic regimes, the dynamics of intertidal populations are also closely linked to biological processes. 


\section{Acknowledgement}

First author is grateful to University Grants Commission, Government of India for the fellowship under Faculty Improvement Programme and to St. Aloysius College, Mangalore for deputation.

\section{References}

Briggs, R.P. 1982. Community structure and growth of Mytilus edulis L. in Lough Foyle. Proceedings of the Royal Irish Academy 82: 245-259.

Commito, J.A. 1987. Adult larval interactions: Predictions, mussels and cocoons. Estuarine, Coastal and Shelf Science 25: $99-606$.

Creese, R.G. and M.J. Kingsford. 1998. Organisms of reef and soft substrata intertidal environments. In: Studying temperate marine environments: a handbook for ecologists. (ed. M.J. Kingsford and C.N. Battershill), pp.167-193. Canterbury University Press, Canterbury.

Davis, C. 1973. Statistics and data analysis in geology. John Wiley, New York.

Dean, T.A. 1981. Structural aspects of sessile invertebrates as organizing forces in an estuarine fouling community. Journal of Experimental Marine Biology and Ecology 53: 163-180.

Fatima, M. 1996. Growth indices, nutritive value and chemical significance of the green mussel. Ph.D Thesis, Institute of Marine Science, University of Karachi, Pakistan.

Grall, J. and L. Chavaud. 2002. Marine eutrophication and benthos: the need for new approaches and concepts.

Global Change Ecology 8: 813-830.

Harger, J.R. 1972. Competitive co-existence: maintenance of interacting associations of the sea mussels Mytilus edulis and Mytilus californianus. The Veliger 14(4): 387-410.

Hasomi, A. 1967. Various types of physical structure of Mytilus edulis population in Suma Coast. Hyogo Biology 5: 237-241.

Joseph, M.M. 1978. Ecological studies on the fauna associated with economic seaweeds of South India -1. Species composition, feeding habits and interrelationships. Seaweed Research and Utilization 3: 9-25.

Kanter, R.G. 1977. Structure and diversity in Mytilus Californianus (Mollusca: Bivalvia) communities. Ph.D. thesis, University of Southern California, Los Angeles, C.A., 93 pp.

Keith, D.E. 1971. Substrate selection in caprelliol amphipods of southern California, with emphasis on Caprella californica Stimpson and Caprella equilibria Say (Amphipoda). Pacific Science 25: 387-394.

Leigh, E.G., R.T. Pain, J.H. Quinn and T.H. Suchanek. 1987. Wave energy and intertidal productivity. Proceedings of the National Academy of Science, (U.S.A.) 84: 1314-1318.

Levington, J. S. 1982. Marine ecology. Prentice-Hall, Englewood cliffs. 526 pp.

Lewis-Bek, S. M. 1994. Factor analysis and related techniques. Sage Publications, London.

Lintas, C. and R. Seed. 1994. Spatial variation in the fauna associated with M. edulis on a wave exposed rockyshore. Journal of Molluscan Studies 60(2): 165-174.

Lohse, D.P. 1993. The importance of secondary substratum in a rocky intertidal community. Journal of Experimental Marine Biology and Ecology 166(1): 1-17.

Loot, G., M. Alane and S.A. Navarrete. 2005. Effects of the human exclusion on parasitism in intertidal food webs of Central Chile. Conservation Biology 19(1): 203-212.

Lubchenco, J., B.A. Menge, S.D. Garrity, P.J. Lubchenco, L.R. Ashkenas, D. Gaines, R. Eralet, J. Lucas and S.

Strauss. 1984. Structure, persistence and role of consumers in a tropical intertidal community (Taboguilla Island, Bay of Panama). Journal of Experimental Marine Biology and Ecology 78: 23-73. 
Madarasz, A. 2003. Factors influencing the community structure of west coast intertidal reefs. MSc thesis, University of Auckland. $136 \mathrm{pp}$.

Menge, B.A. 1991. Relative importance of recruitment and other causes of variation in rocky intertidal community structure. Journal of Experimental Marine Biology and Ecology 146: 69-100.

Menge, B.A. 1992. Community regulation: under what conditions are bottom-up factors important on rocky shores? Ecology 73 (3): 755-765.

Menge, B.A., E.L. Berlow, C.A. Blanchette, S.A. Navarette and S.B. Yamada. 1994. The keystone species concept: variation in interaction strength in a rocky intertidal habitat. Ecological Monographs 64(3): 249-278.

Menge, B.A., J. Lubchenco, L.R. Ashkenas and F. Ramsey. 1986. Experimental separation of the effects of consumers on sessile prey in the low zone of a rocky shore in the Bay of Panama: Direct and indirect consequences of food web complexity. Journal of Experimental Marine Biology and Ecology 106: 225-269.

Naganna C. 1966. Petrology of the rocks of St. Mary's islands, near Malpe, South Kanara district, Mysore State. Journal of Geological Society of India 7: 110-117.

Paine, R.T. 1971. A short term experimental investigation of resource partitionery in a New Zealand rocky intertidal habitat. Ecology 52: 1096-1106.

Paine, R.T. 1976. Biological observations. The Veliger 19(2):125-130.

Paine, R.T. and S.A. Levin. 1981. Intertidal landscapes: disturbance and the dynamics of pattern. Ecological Monographs 51(2):145-178

Petraitis, P.S., E.C. Rhile and S. Dudgeon. 2003. Survivorship of juvenile barnacles and mussels: spatial dependence and the origin of alternative communities. Journal of Experimental Marine Biology and Ecology 293:

217-236.

Pielou, E.C. 1975. Ecological diversity. Wiley, New York. 165 pp.

Porter, E.T., R.I.E. Newell and L.P. Sanford. 1996. Physical and biological scaling of benthic-pelagic coupling in coastal ecosystems: the role of bivalve suspension feeders. Journal of Shellfish Research 15(2): 490491.

Raffaelli, D., E. Bell, G. Weithoff, A. Matsumoto, J.J. Cruz-Motta, P. Kershaw, R.D. Parker Parry and M. Jones. 2003. The ups and downs of benthic ecology: considerations of scale, heterogeneity and surveillance for benthicpelagic coupling. Journal of Experimental Marine Biology and Ecology 285-286: 191-203.

Roughgarden, J., S. Gaines. and H. Possingham. 1988. Recruitment dynamics in complex lifecycles. Science 241: 1460-1466.

Rovero, F., R.N. Hughes and G. Chelazzi. 2000. When time is of the essence: choosing a currency for prey- handling cost. Journal of Animal Ecology 69: 683-689.

Seed, R. 1976. Ecology. In: Marine mussels, their ecology and physiology. (ed. B.L. Bayne), pp.13-66. Cambridge University press, Cambridge.

Seed, R. 1996. Patterns of biodiversity in the macro-invertebrate fauna associated with mussel patches on rocky shores. Journal of Marine Biological Association of the United Kingdom 76: 203-210.

Seed, R. and T. H. Suchanek. 1992. Population and community ecology of Mytilus. In: The Mussel: Ecology, Physiology, Genetics and Culture. (ed. E. Gosling), pp. 87-185. Elsevier, Amsterdam.

Shannon, C.E. and W. Weaner. 1949. The mathematical theory of communication. University of Illinois press, Urbana $117 \mathrm{pp}$.

Strickland, J.D.H. and T.R. Parsons. 1968. A practical hand book of seawater analysis. Fisheries Research Board Bulletin, Canada, 167: 311 pp.

Suchanek, T.H. 1979. The Mytilus Californianus community; studies on the composition structure, organization and dynamics of a mussel bed. Ph.D. thesis, University of Washington, U.S.A.

Suchanek, T.H. 1980. Diversity in natural and artificial mussel bed communities of Mytilus californianus. American Zoologist 20: 807 
Thippeswamy, S. 1990. Community ecology of the green mussel Perna viridis (L.) island microhabitat. Ph.D. thesis submitted to University of Agricultural Sciences, Bangalore, India.

Tsuchiya, M. and M. Nishihira. 1985. Islands of Mytilus as habitat for small intertidal animals, effect of island size on community structure. Marine Ecology- Progress Series. 25: 71-81.

Widdows, J. and P. Donkin. 1992. Mussels and their contaminants: Bioaccumulation and physiological aspects. In: The mussel: Ecology, Physiology, Genetics and Culture (ed. E. Gosling), pp. 383-424. Elsevier, Amsterdam. 